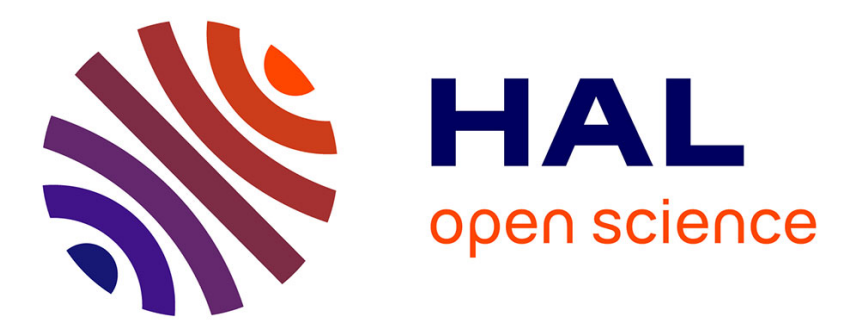

\title{
National Industrial Relations and Local Bargaining Power in the US and German Telecommunications Industries
}

Virginia Doellgast

\section{- To cite this version:}

Virginia Doellgast. National Industrial Relations and Local Bargaining Power in the US and German Telecommunications Industries. European Journal of Industrial Relations, 2008, 14 (3), pp.265-287. 10.1177/0959680108094135 . hal-00570980

\section{HAL Id: hal-00570980 \\ https://hal.science/hal-00570980}

Submitted on 1 Mar 2011

HAL is a multi-disciplinary open access archive for the deposit and dissemination of scientific research documents, whether they are published or not. The documents may come from teaching and research institutions in France or abroad, or from public or private research centers.
L'archive ouverte pluridisciplinaire HAL, est destinée au dépôt et à la diffusion de documents scientifiques de niveau recherche, publiés ou non, émanant des établissements d'enseignement et de recherche français ou étrangers, des laboratoires publics ou privés. 


\title{
Virginia Doellgast
}

King's College London, UK

\section{National Industrial Relations and Local Bargaining Power in the US and German Telecommunications Industries}

\begin{abstract}
This article compares the process and outcomes of collective negotiations over the outsourcing of call centre jobs in US and German telecommunications firms. In the USA, the Communication Workers of America relied on coalitions with politicians and other organizations to lead successful public campaigns; while in Germany, ver.di used coordinated bargaining with works councils to leverage their strong codetermination rights. Variation in access to resources between countries helps explain differences in the unions' ability to negotiate strong collective agreements on outsourcing and to influence restructuring decisions.

KEYWORDS: call centres - Germany - outsourcing - telecommunications - trade unions - USA - works councils
\end{abstract}

\section{Introduction: National Institutions and Local Bargaining Power}

The growing popularity of outsourcing is of particular concern to trade unions, which often lose members and influence as firms move jobs out of core workplaces. However, few studies have examined the causes of unions' varying success in engaging with management over outsourcing decisions (for exceptions, see Hayakawa and Simard, 2001; Pulignano, 2005). Worker representatives typically lack clear bargaining rights over restructuring measures such as outsourcing (Doellgast and Greer, 2007). Union members also often have ambiguous views towards outsourcing, as it may be part of a 'core-periphery' strategy that preserves the high pay and privileges of the in-house workforce. Thus negotiations require considerable communication between the local and national union or between works councils and unions to build alternative forms of bargaining power and support for a set of shared goals.

This study compares union influence on the outsourcing of call centre work, using matched pair case studies of six US and German 
telecommunications firms. It has two goals: to examine the dynamics of collective negotiations over outsourcing in different national settings; and to analyse the factors that explain company-level variation in the outcomes of those negotiations. Industrial relations scholars have debated whether the institutions that influence bargaining outcomes are primarily national or increasingly heterogeneous at the regional or firm level (e.g. Locke, 1992). Today it is widely recognized that unions in both liberal and social market countries rely on a variety of resources to build bargaining power at a time of declining union density and influence (Frege and Kelly, 2003). The notion of a coherent national industrial relations system has been undermined by the growing prevalence of company-level bargaining and flight of employers from peak-level associations (Katz and Darbishire, 2000; Marginson et al., 2003), which has been particularly severe in Germany (Hassel, 1999). Under these conditions, do national institutions still matter for the kinds of tactics and resources unions use to influence local bargaining outcomes?

I argue here that the resources at the sub-national level that are critical for building bargaining power in negotiations over restructuring vary between countries, reflecting differences in bargaining structures and bargaining rights. In Germany, internal coordination between different worker representatives through coordinated bargaining between unions and works councils has long been viewed as the key to union strength (Thelen, 1991). Today, unions' ability to maintain or build these relationships with works councils and the workforce is diminishing, but remains crucial for extending their influence to new sectors and groups of workers across supply chains. Local unions in the USA also benefit from information-sharing and strategy development with the national union (Frost, 2000), but have fewer options to institutionalize these relationships and leverage them in negotiations. This lack of strong institutional supports means that external coalitions and member mobilization are more important for building countervailing power.

In the following sections, I describe the cases and outcome variables; discuss recent changes in markets and industrial relations institutions that have encouraged firms to outsource call centre work; and then analyse variation in union influence over outsourcing. Findings are based on over 200 interviews conducted between 2003 and 2005 with corporate and local managers, works councillors and union representatives, as well as on collective agreements and archival materials.

\section{Case Studies}

The US cases - Verizon Communications East (formerly NYNEX and Bell Atlantic), BellSouth, and AT\&T - are three of the largest competitors in the landline segment of the industry, providing local, long-distance and 
broadband services. All grew out of the former monopoly known as the 'Bell System'. NYNEX, Bell Atlantic, and BellSouth were Regional Bell Operating Companies (RBOCs), or 'Baby Bells', that were divested from AT\&T, or 'Ma Bell', following a court order in 1984. All companies have a long tradition of collective bargaining with the Communication Workers of America (CWA), which since divestiture has remained the dominant union in the industry.

The German cases - T-Com, T-Mobile, and T-Online - were three separate business units of Deutsche Telekom (DT), the former German monopoly provider, at the time of this study. In 2005, T-Online was brought back into the parent company to take advantage of growing synergies between Internet and voice services. However, in 2003 each still serviced different market segments and owned separate networks of call centres. T-Com was the core business unit focusing on local landline and long distance, T-Mobile was responsible for the company's wireless network and services, and T-Online focused on Internet services. All three had strong works councils that negotiated collective agreements and elected representatives to DT's group works council. T-Com and T-Mobile also negotiated company agreements with the service union ver.di, while T-Online never concluded an agreement with ver.di.

In order to analyse variation in negotiations over outsourcing between incumbent firms, it was necessary to accommodate the different structure and history of the incumbent firms in each country. I use two measures of union 'success' to compare outcomes across cases. First, agreements that either bring union-represented jobs in-house or restrict the outsourcing of these jobs are typically advantageous from the union's perspective, as they can increase both the pool of potential union members and workers' job security while limiting management's ability to use the threat of outsourcing to gain concessions. The extent to which unions make concessions on pay and working conditions in exchange for these agreements indicates whether limits on outsourcing are secured using bargaining power or simply traded for job security. Second, the number and kinds of jobs outsourced provides a measure of the impact of these agreements on outsourcing strategies.

\section{Changing Markets and Industrial Relations in Telecommunications}

Until the late 1990s, DT retained its monopoly in fixed line services, but competitive conditions have since become increasingly similar in the two countries. In the USA, the 1996 Telecommunications Act opened up competition in the local telephone market while 1998 legislation in Germany ended DT's monopolies for network infrastructure and fixed-line voice 


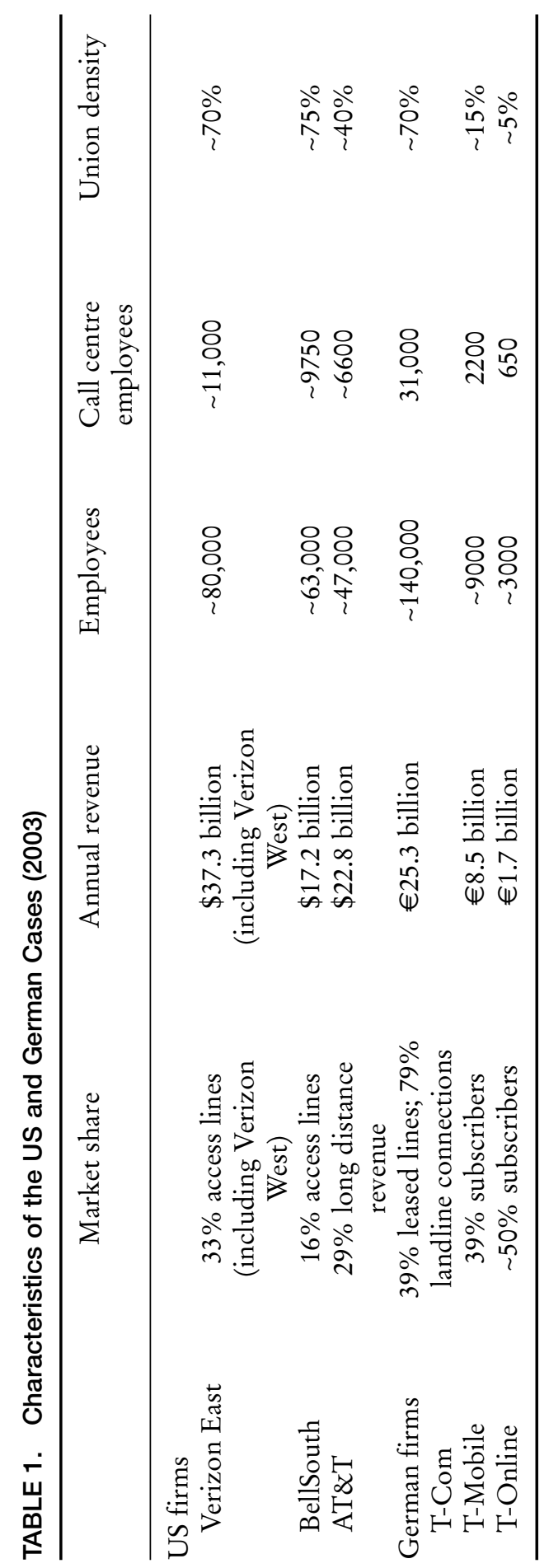


telephony. At the same time, firms in new, less regulated segments such as mobile phones and cable began competing for market share in Internet services and local and long-distance calls.

These changes in markets have contributed to the growing fragmentation of collective bargaining in both countries. In the USA, the CWA and International Brotherhood of Electrical Workers (IBEW) continued to represent workers at the regional Bells and AT\&T following divestiture in 1984. However, national bargaining was soon eliminated, and today bargaining occurs at company, business unit or regional level, depending on the topic and the geographical scope of the company (Keefe and Batt, 1997). In Germany, the Deutche Postgewerkschaft (DPG) negotiated a series of company agreements with DT and its subsidiaries, but no employers' association has been established to negotiate sectorally (Sako and Jackson, 2006). In 2001, the DPG merged with four other service unions to form ver.di, which currently has formal responsibility for representing workers in the industry. However, new competitor firms have either negotiated company agreements with other unions such as IG Metall or remained non-union.

As price competition grew and the non-union sector expanded in both countries, incumbent firms began looking for ways to cut labour costs and improve flexibility, with service and sales jobs a central focus. Reduced long-distance costs and new call distribution technologies made it easier to shift jobs to remote call centres or outsource work to third party vendors - most of which had no or weak collective bargaining institutions. The major telecommunications unions in both countries sought to influence these decisions, but with variable success.

\section{United States: Regional Bells and AT\&T}

The CWA has consistently opposed outsourcing, viewing it as a threat to members' jobs and its own bargaining power. However, the union enjoyed strong leverage over outsourcing at Verizon, moderate success at BellSouth, and failed in negotiations with AT\&T. In all firms, the union encountered different challenges for three areas of call centre work: traditional customer service and sales work, operator services and directory enquiries, and new work, such as outbound sales and technical support.

\section{Verizon East}

Traditional customer service and sales jobs are often difficult to outsource because of their complexity and strategic importance for winning and retaining customers. However, telecommunications firms have attempted to outsource peaks in call volume or 'hive off' lower-skilled tasks to send to third party firms. The CWA has negotiated the strongest 
contractual limits to moving these jobs at Verizon East, prohibiting outsourcing that would involve layoffs or part-time work and the permanent transfer of more than 0.7 percent of CWA-represented jobs from the county or state where it is currently performed. In addition, the union negotiated rules in New York and New England that prevented consolidation of call centres across 'Interdepartment Transfer Areas'. In New York, the company could not close down locations if employees would have to commute more than 35 miles from their original work location. The CWA won an arbitration case prior to 2003 bargaining, forcing Verizon to reinstate over 2000 employees whose jobs had been cut.

Local contracts in the former NYNEX and Bell Atlantic regions also prohibited the subcontracting of certain jobs, like telemarketing or inbound calls. In the mid-1990s, Bell Atlantic formed a non-union subsidiary called Bell Atlantic Plus and began moving some of its core customer service and sales work to the new company at lower pay. In 1998 bargaining, the CWA made this a key issue, and during the ensuing strike the union used a public campaign that highlighted poor customer service at the new subsidiary. Bell Atlantic eventually agreed to bring all of the work in-house and to limit future subcontracting (Katz et al., 2003).

US telecommunications companies downsized operator services in the 1990s and established separate directory enquiries centres, which managers often argued were 'new work' and thus not covered by the contract. Verizon East was the only company where the CWA has succeeded in both keeping this work in-house and avoiding steep pay concessions. Operators were moved into directory enquiries jobs, and pay remained at between $\$ 10$ and $\$ 20$ an hour.

Other new categories of work, including service and sales for new products, technical support and telemarketing, were not covered by contracts at any of the companies, and thus have been most vulnerable to outsourcing. The CWA was successful in in-sourcing a number of these jobs at Verizon. When Verizon East first started selling DSL high speed Internet services, it outsourced inbound sales. The CWA led a successful campaign to bring this work back in-house, arguing that because it was bundled with traditional phone services it fell under 'protected' work in their contract. In New England, the CWA set up a formal partnership with Verizon management in 2003 to reduce absenteeism and improve productivity in the call centres. Committees of local managers and stewards were established, and federal mediators began facilitating regular meetings. After the partnership proved successful in reducing costs, managers agreed to in-source DSL campaign and billing work. As a result, the company's New England customer service and sales centres hired over 200 new representatives between 2004 and 2005, despite losing customers in the region.

Strong agreements limiting outsourcing also gave Verizon incentives to find creative ways of using its higher-cost, difficult-to-downsize eastern 
workforce. For example, as call volumes dropped across New York, local call centres had a surplus of employees, and local managers succeeded in getting some inbound campaign work brought in-house. The union has not been able to halt outsourcing entirely: for example, it was not able to secure an agreement to in-source some 5000 technical support jobs for DSL Internet services, which Verizon continues to outsource to US and offshore locations. However, union representatives were optimistic that they would be able to negotiate an agreement to bring these jobs inhouse.

\section{BellSouth}

The CWA had more limited success at BellSouth, and was forced to make more substantial concessions to keep work in-house. As at Verizon, the contracts prohibited outsourcing if it would involve layoffs or parttime work. However, they did not restrict moving work between locations, which allowed management to consolidate call centres. A small number of jobs that were viewed as less desirable, such as final collections, were outsourced with little resistance from the CWA.

The CWA made more substantial concessions to keep directory enquiries in-house. BellSouth management informed the union in 1997 that it was planning to outsource this work, in anticipation of intensified competition in local services. The CWA agreed to an alternative plan: the company created a new subsidiary to serve BellSouth and other clients, and negotiated a new contract with fewer benefits and pay at roughly half the in-house rate. At the same time, it was also the only contract with BellSouth that prohibited contracting out of work, and the CWA obtained an agreement that BellSouth would not transfer any operator work that had been performed in-house to the new company. According to one CWA representative, the union was faced with 'lose it all or try to build a new bargaining unit'.

The CWA has had similarly mixed results with the outsourcing of 'new work'. In the early 2000s, the company started to outsource its online customer support, but the union was able to use political pressure to convince management to perform the work in-house. Now 125 'web reps' handle these jobs in a separate call centre, under the traditional customer service contract. In 2004 bargaining, the company signed a letter of agreement with the CWA to work together to move other 'jobs of the future' - such as Voiceover Internet Protocol, wireless Internet, and video sales and support - into the bargaining unit. However, union representatives remained sceptical whether management would follow through on this pledge, and had not yet begun negotiations on pay or working conditions for the new jobs. BellSouth also outsourced all telemarketing work in 1998 and some outbound collections work in 2000. 


\section{AT\&T}

The CWA has had the least success at AT\&T. Managers circumvented contract provisions prohibiting outsourcing by moving core customer service and sales work outside the 'Geographic Service Area' of 35 miles. Before 1997, AT\&T routed 'low value' customers, with bills of under $\$ 50$ a month, to a vendor, while the higher-value customers were still serviced by the in-house workforce. Then in the late 1990s, AT\&T began to outsource and offshore most remaining long-distance work, keeping several domestic call centres open as benchmarks for vendor performance. By 2004, AT\&T was outsourcing 45 percent of its calls, including two-thirds of its long-distance calls. Between January 1999 and December 2003, the number of in-house customer service employees dropped from 7500 to 3300 , while the number at subcontractors employed on AT\&T's accounts grew from 830 to around 3500 .

In 2001, the CWA initiated a partnership with AT\&T to develop a joint plan to in-source this work, using leverage over the regulatory approval that the company needed to divest its wireless, broadband and manufacturing equipment. AT\&T provided detailed information on its outsourcing activities and data on the cost difference between the in-house and outsourced workforce, which it estimated at around 40 percent. After recalculating to reflect higher quality, productivity and sales at union centres, the CWA narrowed the cost difference to 15 percent for domestic outsourcing and 30 percent for outsourcing to India. The CWA and $\mathrm{AT} \& \mathrm{~T}$ also formed a joint committee to address absenteeism at in-house call centres, which resulted in a pilot project to introduce job rotation and flexible scheduling. The union demonstrated positive effects on morale, and management agreed to extend the pilot.

These various initiatives were cut short in 2004 when AT\&T decided to pull out of the residential long distance market following a regulatory change. AT\&T subsequently closed several of its own domestic call centres, leading to a loss of around 550 union jobs, and cut a thousand vendor jobs. AT\&T also unilaterally outsourced directory enquiries work, moving all new calls to several vendors in the early 1990s. In 1997, managers approached the CWA to discuss bringing some of this work in-house, and eventually created a separate group of operators at a lower pay scale, starting at $\$ 6.30$ an hour at a time when other operators in the company were making over $\$ 20$ an hour. However, AT\&T was unable to create sustained demand for the new service, and in 2004 it closed the centres and laid off the last of their dwindling workforce. AT\&T was also the first of CWA's employers to outsource outbound telemarketing work on a large scale. Following divestiture, AT\&T moved all telemarketing calls to its nonunion subsidiary Transtech, with hourly wages at roughly half the equivalent pay for union members. The CWA attempted to organize Transtech in the early to mid-1990s, but was unsuccessful. 


\section{Comparison}

Table 2 compares contractual protections against outsourcing work and outsourcing strategies. Verizon East had the strongest agreements and least extensive outsourcing, AT\&T had the weakest agreements and most extensive outsourcing, while BellSouth had mixed outcomes.

What explains the differences between these three cases? Competitive pressures varied: AT\&T came under earlier pressure to cut costs when the long-distance market was liberalized in the late 1980s. However, Verizon East and BellSouth also faced growing price competition from the late 1990s, and still kept more core customer service and sales work in-house than AT\&T. In addition, the CWA was able to prevent directory enquiries and 'new work' from being outsourced under strong agreements at Verizon but had more mixed outcomes at BellSouth, although both companies enjoyed stable regional monopolies.

A second difference may be in employer strategies. AT\&T adopted a cost-cutting strategy earlier than the two 'baby Bells', in response to intense price competition in the long-distance segment. This encouraged management to outsource aggressively while Verizon and BellSouth continued to view their in-house call centre workforce as a key asset for building sales in new segments. However, two pieces of evidence suggest that outcomes are not solely or primarily driven by these differing strategies. First, interviews with managers at both Verizon and BellSouth made it clear that they would prefer to increase their use of outsourcing or offshoring to cut costs, but were explicitly limited from doing so by their union contracts and the threat of negative publicity from union-led campaigns. Second, at all three firms, management had adopted similar outsourcing strategies, such as setting up non-union subsidiaries or subcontracting lower-skilled jobs; but only reversed these strategies following union pressure at Verizon (and to a lesser extent at BellSouth).

The case studies suggest that variation in agreements on outsourcing and actual company practices were strongly influenced by the CWA's success in building bargaining power at company level, using the resources of external coalitions and member mobilization. Before divestiture, the CWA played an important role in lobbying state Public Service Commissions (PSCs) on behalf of employer applications for rate increases. The union learned to leverage this support, together with joint campaigns with other unions, community groups, and local politicians, in exchange for favourable agreements with the regional Bells. These coalition strategies in turn relied on the union's ability to show strong internal solidarity through strikes and other forms of direct action.

The CWA could best combine these resources at Verizon East because of strong membership density, location in states with strong labour laws, a tradition of local militancy and a legacy of strong collective agreements secured through several successful campaigns in the 1980s and 1990s. 


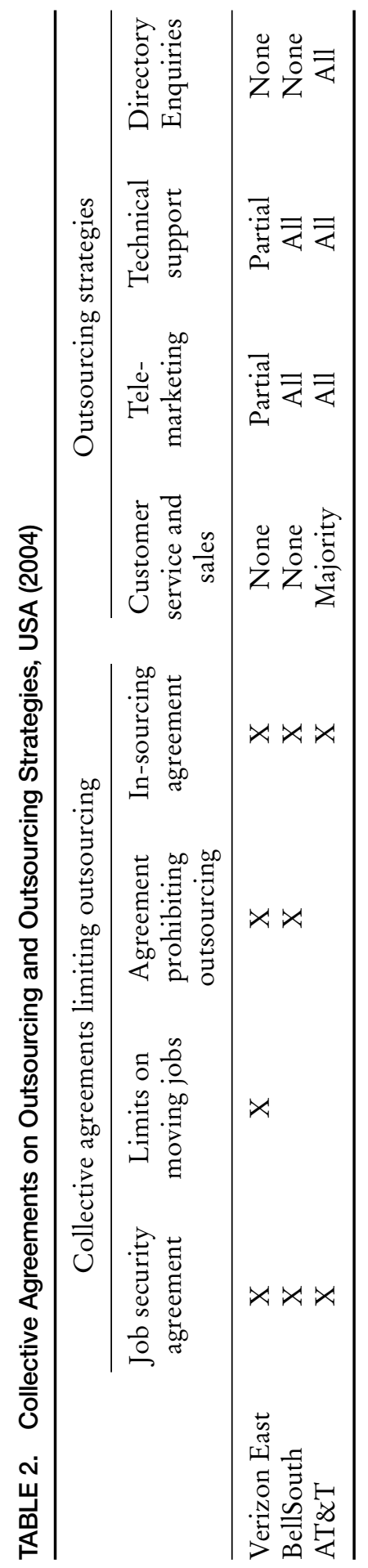


During a 17-week strike in 1989 against reductions in health care provision the union also adopted a new set of strategies that combined political lobbying and coalitions with community groups to bolster its position at the bargaining table, working with the IBEW for the first time to coordinate a campaign of public petitions, rallies and pickets. For the first time it opposed a rate increase that NYNEX had requested from the PSC; and CWA representatives used their personal connections with New York's democratic Governor, Mario Cuomo, to build additional pressure. This resulted in a largely successful settlement, when broader concessions were made in other former Bell companies.

The CWA later used a similar approach when it publicly supported the merger between NYNEX and Bell Atlantic in 1998 in exchange for a series of agreements that would become important for preventing or reversing outsourcing. In addition, the union coordinated a campaign in 1998 that embarrassed Bell Atlantic into bringing core work from its non-union call centre subsidiary back in-house. This relied on strikes and public advertisements highlighting poor customer service, both of which were supported by a well-organized membership base.

At BellSouth and AT\&T, the CWA sought to use similar tactics, but was less successful. BellSouth was based in 'right-to-work' states where the CWA could not apply a closed shop, which made it more difficult to organize members and to mount prolonged strikes. The union also enjoyed less political support in these regions. In contrast to the Bells, AT\&T was a national company, and so had broader scope for moving work to regions with cheaper labour costs and looser regulations. AT\&T was also regulated by the Federal Communications Commission (FCC) rather than state PSCs, which made it more difficult to use state-level lobbying (Batt and Darbishire, 1997). To compensate for this weaker position, the CWA relied more heavily on partnership agreements at the two companies, without the kind of backing from a militant membership and external coalitions enjoyed at Verizon East. However, these were discontinued following unpopular restructuring measures in the late 1990s and early 2000s (including outsourcing) that were imposed unilaterally by management.

\section{Germany: Deutsche Telekom}

At DT's three core business units - T-Com, T-Mobile, and T-Online - the DPG (later ver.di) and the works councils initially viewed outsourcing as a compromise that allowed management to cut costs while protecting members' working conditions. However, they began to oppose outsourcing as market growth slowed, as benchmarking with subcontractors increased, and as management began to push more aggressively for layoffs. As in the 
USA, the union's success in negotiations over outsourcing varied across firms, with strong agreements at T-Com, mixed outcomes at T-Mobile and general failure at T-Online. Because there has been less segmentation of call centre work in Germany compared to the USA, I focus here on strategies toward core customer service and sales work and lower-skilled jobs such as directory enquiries and telemarketing.

\section{T-Com}

DT's landline division, T-Com, faced growing price competition and a declining customer base in the late 1990s, as in AT\&T and the regional Bells. However, management did not outsource its core customer service and sales jobs. This was due in part to the complexity and strategic importance attached to this work (Matuschek et al., 2007), but was also influenced by strong collectively negotiated constraints, including Standortsicherungsverträge (location security agreements) and job security protections. As a former public company, T-Com retained a number of Beamten (civil servants) who enjoy lifetime job security. The DPG also succeeded in maintaining and extending job security agreements that prevented involuntary layoffs.

The difficulties this posed for reducing employment shaped subsequent organizational strategies. Between 1995 and 2004, DT cut 110,000 positions in its core operations, largely through early retirement, voluntary redundancy and natural turnover. Redundant employees who did not accept these options were moved into a 'temporary employment and qualification company', or Beschäftigungsgesellschaft, set up in 2002, which placed employees on short-term assignments both within and outside the company. These arrangements were expensive, and management began to put pressure on union and works council representatives to cooperate with cost-cutting measures (Holtgrewe, 2006). In 1998, the DPG agreed to allow management to shift directory enquiries jobs to a vendor in exchange for pay increases for the in-house workforce. T-Com outsourced 2800 of its 3500 directory enquiries jobs, and surplus employees were moved to new jobs in T-Com or in DT's other subsidiaries. The company also reorganized special campaign work, remaining directory enquiries work and late night work into a subsidiary and outsourced some outbound telemarketing work to third-party vendors.

By 2003, DT's internal temporary placement agency had close to 20,000 employees, entitled to their former rates of pay even if managers were unable to find work for them. In January 2004, DT set up a new call centre subsidiary to provide employment for these workers called Vivento Customer Services (VCS), to handle the corporate group's lower-skilled service and sales work, allow the company to in-source directory enquiries jobs, and eventually compete in the call centre vendor market. 
In 2003, DT announced future cuts of up to 40,000 jobs and made it clear that without concessions, management would not extend job security agreements. In March 2004, ver.di concluded an employment pact with the company that reduced working time from 38 to 34 hours with only partial wage compensation. In return, job security protections were extended until the end of 2008. Ver.di was also able to keep VCS under the DT collective agreement with guaranteed job security but with a 8.75 percent reduction in pay.

Ver.di saw the creation of VCS as a positive development that would allow the company to take back thousands of jobs that had been outsourced to vendors under a strong collective agreement. With a planned expansion to over 5000 employees, it would be the largest call centre vendor in Germany. This represented a shift in ver.di's position, since union officials came to view outsourcing as a threat to their members and their organization as managers started benchmarking costs against vendors. Works councils were more divided, as they feared that more work would be moved from T-Com's call centres to VCS. Ver.di and the T-Com works councils were thus cautiously cooperating with the new VCS plan, helping DT to find new markets for the workforce while keeping the pressure on management to keep 'core' work in the company's sales and service centres.

\section{T-Mobile}

In contrast to T-Com, T-Mobile enjoyed stable growth in call volume and employment throughout the 1990s as the wireless market expanded. This allowed the company to increase its use of subcontractors for core service and sales calls without threatening the jobs of its in-house workforce. T-Mobile built up its call centres and brought in surplus employees from T-Com, while simultaneously outsourcing peaks in call volume, vacations, night shifts, and outbound campaigns to provide additional flexibility and benchmark agent performance.

Works councils at T-Mobile originally saw outsourcing as a complementary strategy to improving job security and avoiding unsocial working times. By the late 1990s, however, growth in the market had slowed and several alternative network providers had expanded their market share. In early 2000, T-Mobile closed one of its call centres and began subcontracting a larger proportion of its core work. As a result, job security and outsourcing became central issues in the 2002-03 bargaining round. Management wanted to outsource more work while the union and works councils were strongly opposed. After difficult negotiations, T-Mobile agreed that no locations would be closed until 2008 but that additional call volume could be subcontracted out as long as no jobs were lost. In return, the works councils approved a more flexible working time 
model that they had previously opposed and ver.di agreed to a 1 percent pay rise instead of the 2.1 percent it had demanded. They also agreed that calls during 'unsocial' hours - when employees had been entitled to overtime pay - could be outsourced to cheaper providers.

\section{T-Online}

T-Online was the only subsidiary without a union-negotiated collective agreement, although it did have works agreements negotiated by the company's strong works councils. T-Online took over call centre locations from T-Com as the online business expanded, allowing some continuity in works council leadership. In the late 1990s, the company first began focusing on customer service in response to rising call volume and complaints, and in a few years grew to five locations with between 300 to 350 employees in each.

Then in 2002, T-Online sold three of these locations to different call centre vendors. The company retained two locations in Kiel and Oldenburg, which today handle mostly second-level technical support. Managers kept around 10 percent of first-level technical support inhouse to benchmark vendor performance, but subcontracted out the other 90 percent. Ver.di and the central works council went through four rounds of negotiations, and eventually secured an agreement that pay and working conditions would remain the same for 18 months after the new companies took over, along with full job security and extension of previous agreements with the works councils. After this time, the new companies were free to renegotiate their employment contracts or to move the calls to their other locations.

The decision to outsource these jobs increased pressure on the in-house workforce to agree to concessions, given the growing difference in pay and working conditions between in-house and outsourced call centres. For example, the T-Online works council negotiated strong agreements protecting its call centre employees from silent monitoring and individual evaluation. However, some works councillors considered relaxing these rules to improve their 'competitiveness', following a successful pilot at the company's vendors of a new monitoring programme that allowed supervisors to collect and analyse detailed data on individual agent performance. One works councillor described being verbally attacked by employees at the annual meeting for not giving in to employer demands and thus threatening their jobs.

A new round of negotiations with ver.di followed DT's decision to bring T-Online into the parent company in 2005. The original agreement between T-Online and DT laying out the conditions of the merger included a plan to outsource the Kiel and Oldenburg locations, but ver.di 
won an agreement to integrate all locations and employees into T-Com. Managers also agreed to a 38 hour week across T-Online, and were not able to lay off employees or close locations until a new collective agreement was negotiated under T-Com. At the same time, most of the company's online work would continue to be outsourced.

\section{Comparison}

Table 3 compares collective agreements on outsourcing and outsourcing strategies in the German cases. T-Com had the most favourable outcomes, T-Mobile traded limits against larger concessions on pay and working conditions, while T-Online had no formal agreements and outsourced the majority of call centre jobs.

What explains the variation across the three companies? Again, competitive pressures differed. T-Mobile and T-Online expanded employment in the 1990s in response to market growth, and thus works councillors were more willing to accept some outsourcing of core work; while T-Com's works councillors opposed restructuring measures that could lead to job cuts at a time when their company was downsizing. However, these differences explain the strength of union resistance rather than differences in external pressures on employers - if anything, T-Com had more of an incentive to outsource work than the mobile and online subsidiaries, as it faced the most intense price competition (like AT\&T). In addition, cost cutting pressures and worker attitudes towards outsourcing have become more similar in the three firms as competition increased and market growth slowed across the sectors.

Employer strategies may also help to explain variation in outcomes. T-Com management has more continuity from the old Bundespost and still values close relationships with worker representatives. T-Online's managers were more often recruited externally and developed a reputation for independence from the parent company, which may explain both their aggressive approach towards outsourcing and their resistance to negotiating a collective agreement. However, as with the US cases, managers at T-Com and T-Mobile made it clear in interviews and through their actions that they did not feel free to pursue a unilateral strategy of outsourcing, despite the attractiveness in terms of cost savings and flexibility.

As in the USA, variation across the companies in the union's bargaining power provides an important explanation for these differences. However, while the CWA relied on strong external coalitions, ver.di depended on access to strong coordinated bargaining structures at company level, again supported by its ability to mobilize a well-organized base of union members. 


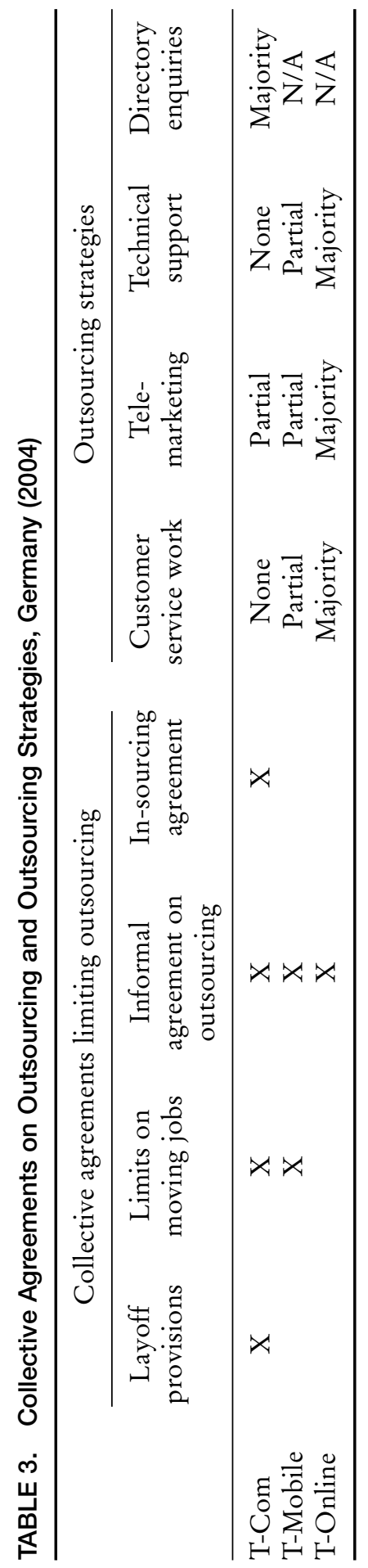


After DT adopted a divisional structure in the late 1990s, T-Com was the only major division that remained legally within the parent company. This meant that there was continuity in employment and bargaining structures from the old public monopoly. Membership density remained close to 70 percent, and around 30 percent of employees were Beamten with lifetime job security. When T-Mobile and T-Online were established as separate subsidiaries, managers sought to recruit a younger, more flexible workforce. Employees had the option to move from T-Com to the subsidiaries, typically with higher pay, but were required to take temporary leave from their Beamte status, which they would then lose after five years if they did not transfer back. Younger employees were more likely to take this option. Both these transferred employees and new hires lacked the strong historical ties to the DPG found in T-Com, and union density was lower, at around 15 percent at T-Mobile and 5 percent at T-Online. While most works councillors at the three companies were ver.di members, communication with their colleagues at other locations or with the union remained strongest at T-Com, was being strengthened at T-Mobile, but was still quite weak at T-Online.

This difference in the history and structure of bargaining influenced the level of information exchange and coordinated strategy development between worker representatives. At T-Com, considerable consultation occurred at different levels. Union and works council members on the supervisory board were informed about organizational restructuring decisions well in advance, and in some cases, special committees provided an additional forum for consultation over issues that unions and works councils viewed as strategically important. For example, a joint Innovation and Employment Advisory Committee (Innovations- und Beschäftigungsbeirat) was established in the late 1990s. T-Com managers felt that they could not implement major restructuring decisions without consulting the union, and every month a permanent board of company representatives informed works council representatives about re-engineering plans. This bargaining power, combined with the strong job security protections that were a legacy of the company's public sector history, meant that ver.di was able to negotiate an agreement to in-source directory enquiries with only marginal pay concessions, while extending job security protections.

At T-Mobile, works councillors felt that ver.di played an important role in negotiating collective agreements and supporting the works councils, but noted that they were not in frequent contact with the union and received more support from the central works council. Worker representatives at all three companies agreed that the union was considerably weaker in the subsidiaries, which made it more difficult to convince works councils to take a solidaristic position on outsourcing across locations. Several T-Mobile works councillors said that while they supported 
ver.di, they did not see it as their job to convince workers to become members.

As at T-Com, T-Mobile union and works council representatives also pointed to coordinated bargaining as the key to their success in getting a collective agreement in 2003 that improved job security protections and limited future outsourcing. At the same time, the works councils made substantial concessions in working time flexibility and the union settled on a small overall pay increase to secure this agreement.

At T-Online, this kind of coordinated campaign was not possible during negotiations over the 2002 decision to outsource three call centres to thirdparty vendors. Ver.di did not yet have a collective agreement with T-Online and played only a marginal role in working with the works councils to develop a coordinated strategy. This exacerbated the problem of competition across locations for jobs, which was manifest in the lack of solidarity among T-Online's works councils at the time of negotiations over outsourcing. Works councils at locations that remained in the company did not oppose the decision, as they had secured job security agreements for their own members.

Since the conclusion of my research, outsourcing has become an even more contentious and public issue at DT. In 2006, it transferred five of the 19 call centres in its Vivento CS subsidiary, with around 700 employees, to two subcontractors. Employees' pay and working conditions were secured until 2008, but after that time the new employers will presumably renegotiate contracts at a lower level. In 2006, ver.di also agreed to reduced starting pay for new hires in T-Mobile's call centres. This followed an emotional campaign in which management threatened to sell its call centres to a vendor if its terms were not accepted.

Then in 2007 DT announced plans to shift 50,000 of its technical service, technical infrastructure, and call centre jobs into three new subsidiaries, and demanded the renegotiation of pay and working conditions in these subsidiaries. Although ver.di led a six week strike with strong support from its membership, both parties eventually agreed to reduce wage levels for current employees by 6.5 percent over 42 months and increase working time from 34 to 38 weeks without pay compensation. In addition, new employees will earn 30 percent below the current level, the use of variable pay will increase, and the regular working week in call centres will include Saturdays. Management agreed to extend job security until 2012 and to not sell the new service subsidiaries until 2010. An important factor in ver.di's decision to return to negotiations was management's threat to transfer employees to the new companies without a collective agreement. This will have further negative implications for the coordination of bargaining within DT, as works councils will be obliged to develop a new structure for decision-making at each business unit and across the corporation. 
These recent developments suggest that the decentralization of collective bargaining, growth of a non-union sector, and increased price competition in the German telecommunications industry are further weakening ver.di's ability to rely on its traditional forms of bargaining power - even in the company's traditional 'core' business. The result will be growing convergence in employment conditions and outsourcing strategies across DT's business units, as well as increased labour market segmentation across the corporation and its subcontractors.

\section{Discussion}

Industrial relations scholars have long argued that national institutions provide German unions with distinctive forms of bargaining leverage in negotiations over restructuring decisions. The causal relationship between national institutions and local bargaining outcomes is less transparent today, as union density and bargaining coverage decline and as employer strategies become increasingly varied at the firm- and establishment-level. One argument holds that strong representation rights and encompassing bargaining structures in Germany continue to provide workers with the tools to exercise some measure of industrial democracy lacking in the USA (Croucher and Singe, 2002; Katz and Darbishire, 2000). Other scholars argue that unions' bargaining power has been substantially weakened as decentralization allows firms an 'exit' from expensive collective bargaining arrangements (Hassel, 1999; Menz, 2005). This article has contributed to this debate by shifting the focus away from macro-level trends in the scope and organization of bargaining, and exploring how unions actually use different institutions to build bargaining power and influence restructuring outcomes.

The case studies show that union success in engaging with management over outsourcing decisions differed within rather than between the USA and Germany. Unions in both countries had uneven access to three resources identified in past studies of work restructuring: internal coordination, external coalitions and member mobilization. However, the relative importance of these resources to unions' success differed between the countries. In the USA, the CWA relied on external coalitions backed up by member mobilization to compensate for weaker bargaining rights and more fragmented bargaining structures. Bargaining power was strongest at Verizon East because of favourable labour laws, high union density, a militant and well-organized membership base, relationships with local politicians and other unions and lobbying influence at state regulatory agencies. In Germany, ver.di relied on strong internal coordination, again supported by a well-organized membership base. The union enjoyed the 
greatest influence over outsourcing decisions in T-Com, where it was able to use its close relationships with works councils and its members to negotiate strong collective agreements and encourage alternative investment strategies.

These findings suggest that the distinctive features of national industrial relations institutions continue to play an important role in negotiations over restructuring, but are becoming less useful as static variables that explain company-level variation in restructuring outcomes. Worker representatives remain embedded in their respective political and economic environment and are still dependent on labour laws and bargaining arrangements to gain advantage at the bargaining table. However, in both the USA and Germany, decentralization has put unions under similar pressure to innovate, using old resources in new ways. This is by no means a new development - the meaning and use of industrial relations institutions have varied more considerably over time than their formal rules and structures. Jackson (2005), for example, has pointed out that German codetermination has gone through considerable changes as actors used relatively stable institutions in creative ways in response to new challenges. What does seem to be new is the extent of variation in the outcomes of this process within social market countries like Germany, where unions were traditionally able to extend bargaining gains across firms in an industry. DT's recent unilateral decision to move its call centre jobs to a separate subsidiary suggests that even established sources of bargaining leverage can be undermined by increasing cost-based pressures and shifting organizational strategies.

The generalizability of these findings may be limited by several factors. First, the telecommunications industry has a number of unique characteristics. In both the USA and Germany, it was long organized as a national monopoly that negotiated with one major union, and its market position continues to be heavily dependent on national and regional regulation. The CWA's bargaining power is strengthened by its ability to leverage established relationships with regulatory agencies and politicians. Meanwhile, ver.di's bargaining position has been substantially weakened by the rapid entry of non-union firms to the German telecommunications market and the lack of a sectoral agreement. A comparison with negotiations over outsourcing in other industries, such as car manufacturing, may reveal greater cross-national variation in outcomes. At the same time, it is striking that such large differences can be observed across the business units of DT, a single, large German employer, that are comparable to those found between the separate companies of the former Bell system in the USA.

By focusing on core employers, I have chosen cases where unions are most likely to enjoy institutionalized channels of influence. German unions may adopt similar strategies to US unions in new industries or 
firms, where they lack strong relationships with works councils or established positions on supervisory boards. At the same time, several recent studies have found that German unions have had broader difficulties implementing new strategies that rely on coalition-building or external forms of public pressure to organize new industries and groups of workers (Aust and Holst, 2006; Baccaro et al., 2003). The lack of a tradition of more confrontational strategies, which developed in the USA under conditions of weak labour laws, may prove a greater obstacle to new organizing efforts.

Unions' influence over management practices and working conditions increasingly depends on their ability to negotiate agreements that limit outsourcing. The findings from this study demonstrate that unions in both liberal and social market countries can gain an independent voice in these restructuring decisions through using traditional forms of bargaining power in innovative ways. However, they are unlikely to sustain their access to increasingly scarce resources and to shape the future production strategies of firms without considerable effort, creativity and organized political action.

\section{ACKNOWLEDGEMENTS}

The research was supported by grants from the Alfred P. Sloan Foundation, the Council for European Studies, the Fulbright Foundation, the Mario Einaudi Center for International Studies at Cornell University, the Max Planck Institute for the Study of Societies and the Russell Sage Foundation. The author thanks Stephen Bach, Rose Batt, Debbie Goldman, Howard Gospel, Ian Greer, Marco Hauptmeier, Ursula Holtgrewe and Gregory Jackson for detailed comments on earlier drafts.

\section{REFERENCES}

Aust, A. and Holst, H. (2006) 'Von der Ignoranz zur Organisierung? Gewerkschaftliche Strategien im Umgang mit atypisch Beschäftigten am Beispiel von Callcentren und Leiharbeit', Industrielle Beziehungen 13(4): 291-313.

Baccaro, L., Hamann, K. and Turner, L. (2003) 'The Politics of Labour Movement Revitalization: The Need for a Revitalized Perspective', European Journal of Industrial Relations 9(1): 119-33.

Batt, R. and Darbishire, O. (1997) 'Institutional Determinants of Deregulation and Restructuring in Telecommunications: Britain, Germany and the United States Compared', International Contributions to Labour Studies 7: 59-79.

Croucher, R. and Singe, I. (2002) 'Flexible Working Time and Interest Representation in German and British Banking', in I.U. Zeytinoglu (ed.) Flexible Work Arrangements: Conceptualizations and International Experiences, pp. 147-60. London: Kluwer Law International. 
Doellgast, V. and Greer, I. (2007) 'Vertical Disintegration and the Disorganisation of German Industrial Relations', British Journal of Industrial Relations 45(1): 55-76.

FCC (2005) 'Trends in Telephone Service', Federal Communications Commission, Washington, DC.

Frege, C. and Kelly, J. (2003) 'Union Revitalization Strategies in Comparative Perspective', European Journal of Industrial Relations 9(1): 7-24.

Frost, A. (2000) 'Explaining Variation in Workplace Restructuring: The Role of Local Union Capabilities', Industrial and Labor Relations Review 53(4): 559-68.

Hassel, A. (1999) 'The Erosion of the German System of Industrial Relations', British Journal of Industrial Relations 37(3): 483-505.

Hayakawa, S. and Simard, F. (2001) 'Contracting Out in Japanese Local Government: Are Unions Making a Difference?', British Journal of Industrial Relations 39(1): 81-95.

Holtgrewe, U. (2006) Flexible Menschen in flexiblen Organisationen: Bedingungen und Möglichkeiten kreativen und innovativen Handelns. Berlin: Edition Sigma.

Jackson, G. (2005) 'Contested Boundaries: Ambiguity and Creativity in the Evolution of German Codetermination', in W. Streeck and K. Thelen (ed.) Beyond Continuity: Institutional Change in Advanced Political Economies, pp. 229-54. Oxford: Oxford University Press.

Katz, H. and Darbishire, O. (2000) Converging Divergences. Ithaca, NY: ILR Press.

Katz, H.C., Batt, R. and Keefe, J.H. (2003) 'The Revitalization of the CWA: Integrating Collective Bargaining, Political Action, and Organizing', Industrial and Labor Relations Review 56(4): 573-89.

Keefe, J. and Batt, R. (1997) 'United States', in H.C. Katz (ed.) Telecommunications: Restructuring and Employment Relations Worldwide, pp. 31-88. Ithaca, NY: ILR Press.

Locke, R. (1992) 'The Demise of the National Union in Italy: Lessons for Comparative Industrial Relations Theory', Industrial and Labor Relations Review 45(2): 229-49.

Marginson, P., Sisson, K. and Arrowsmith, J. (2003) 'Between Decentralization and Europeanization: Sectoral Bargaining in Four Countries and Two Sectors', European Journal of Industrial Relations 9(2): 163-87.

Matuschek, I., Arnold, K. and Voss, G.G. (2007) Subjektivierte Taylorisierung: Organisation und Praxis medienvermittelter Dienstleistungsarbeit. Munich: Rainer Hampp Verlag.

Menz, G. (2005) 'Old Bottles - New Wine: The New Dynamics of Industrial Relations', German Politics 14(2): 196-207.

Pulignano, V. (2005) 'Union Responses to "Multi-enterprise" Factories in the Italian Motor Industry’, Industrial Relations Journal 36(2): 157-73.

Sako, M. and Jackson, G. (2006) 'Strategy Meets Institutions: The Transformation of Labor Relations at Deutsche Telekom and NTT', Industrial and Labor Relations Review 59(3): 347-66.

Thelen, K. (1991) Union of Parts: Labor Politics in Postwar Germany. Ithaca, NY: Cornell University Press. 
VIRGINIA DOELLGAST is Lecturer in Comparative HRM at King's College London.

ADDRESS: Department of Management, King's College London, 150

Stamford Street, London SE1 9NH, UK. [e-mail: virginia.doellgast@kcl.ac.uk] 